\title{
Construction Fractional Genomic Libraries and Screening Microsatellites DNA of Esox reieherti Dybowski
}

\author{
WANG Hong-zhe ${ }^{1,2}$, YIN Qian-qian ${ }^{1,2}$, FENG Zhi-gang ${ }^{2}$, \\ LI Da-yu ${ }^{1,2}$, SUN Xiao-wen ${ }^{1, *}$, LI Chan ${ }^{1,2}$ \\ (1. Heilongjiang River Fisheries Research Institute, Chinese Academy of Fisheries Science, Harbin 150070, China; \\ 2. Life Science and Technology Institute, Dalian Fisheries College, Dalian 116023, China )
}

\begin{abstract}
Esox reieherti Dybowsk genomic microsatellites were developed by using enrichment protocols combined with radioactive hybridization protocol. Four hundred to nine hundred base pair fragments were selected for the whole genome. DNA PCR amplification after digestion with restriction endonuclease Sau 3A I, and (CA) $)_{12},(\mathrm{GA})_{12}$ probes marked with biotin were used for microsatellite DNA enrichment. The product fragments were connected with carrier pGEM-T and transferred into DH5 $\alpha$ Escherichia coli competent cells, and radioactive isotope probes marked with $\gamma^{-32} \mathrm{P}$ were used for the second hybridization. As a result, a total of 1600 bacteria were obtained in the microsatellite genomic libraries, positive clones accounted for $90.91 \%$ before hybridization and $81.25 \%$ after hybridization, amounting to 1300 . One hundred and ninety-six positive clones were selected for sequencing, and 192 clones included microsatellite sequences. The microsatellite sequences obtained, mono-nucleotide, quad-nucleotide and quint-nucleotide repeat motifs were observed beside double-base-pairs CA/GT, GA/CT. Seventy primers were designed according to the flanking sequences by using software Primer Premier 5.0, and 32 primers were selected to be synthesized. After optimizing PCR reaction conditions, 28 primers were amplified and produced clear purpose bands. The aim of our research was to promote the development and utilization of E. reieherti genomic resource, and lay the foundation for optimizing E. reieherti breeding strain in order to detect the genetic diversity and construct a genetic map.
\end{abstract}

Key words: Esox reieheri Dybowsk; Microsatellite DNA; Magnetic beads enrichment protocol

\section{黑斑狗鱼部分基因组文库构建和微卫星位点的篮选 \\ 王洪哲 ${ }^{1,2}$, 殷倩茜 ${ }^{1,2}$, 冯志纲 ${ }^{2}$, 李大宇 ${ }^{1,2}$, 孙效文 ${ }^{1, *}$ ，李 婵 ${ }^{1,2}$ \\ (1. 中国水产科学研究院 黑龙江水产研究所, 哈尔滨 $150070 ; 2$. 大连水产学院 生命科学与技术学院, 大连 116023)}

摘要: 采用磁珠富集与放射性杂交相结合的方法开发黑斑狗鱼（Esox reieherti Dybowski）基因组微卫星资源。 基因组 DNA 经 Sau 3A I 限制性内切酶消化后, 选取 400-900bp 的片段进行 PCR 全基因组扩增, 并利用生物素 标记的（CA） 12 、（GA） 12 探针进行微卫星片段的富集。将得到的片段与 pGEM-T 载体连接后转入 DH5 $\alpha$ 大肠 杆菌中, 然后利用 $\gamma^{-32} \mathrm{P}$ 标记的放射性同位素探针进行第二次杂交。结果, 共获得微卫星基因组文库 1600 个菌, 杂交前菌落 PCR 检测阳性克隆率为 $90.91 \%$; 杂交后得到的阳性克隆为 1300 个, 占 $87.25 \%$ 。从中挑出 196 个进 行测序, $192(97.96 \%)$ 个含有微卫星序列。在得到的微卫星序列中, 重复单元除 CA/GT、GA/CT 外, 还观察到 单碱基、四碱基、五碱基重复单元。根据侧翼序列应用引物设计软件 Primer Premier 5.0 设计引物 70 对, 选择合 成 32 对, 通过优化 PCR 反应条件, 结果有 28 对引物可扩增出清晰可重复的目的条带。本研究旨在对黑斑狗鱼基 因组资源的开发利用起到一定的促进作用，并为黑斑狗鱼养殖品系的优化、遗传多样性的检测及遗传图谱的构建 等奠定基础。

关键词: 黑斑狗鱼; 微卫星; 磁珠富集

中图分类号: Q959.4; Q751；S917 文献标识码：A＼cjkstart文章编号：0254-5853-(2008)03-0245-08

Received date: 2008-03-17; Accepted date: 2008-04-25

Foundation item: Supported by Platform Construction of National Science and Technology Basic Research.(2005DKA30470-005)

收稿日期：2008-03-17;接受日期：2008-04-25

基金项目：国家科技基础条件平台建设（2005DKA30470-005）

*通讯作者(Corresponding author), E-mail : sunxw2002@163.com

第一作者简介: 王洪哲(1978- ), 男, 辽宁锦州人, 硕士研究生, 主要从事水产动物遗传育种研究。E-mail: hongzhewang21@sina.com 
Esox reieherti Dybowski, Salmoniformes, Esocoidei, Esocidae, Esox, is characterized as a cold water fish in Heilongjiang River, widely distributed in Asia, Europe and North America, but only found in Heilongjiang River valley in China. Esox reiehert has great economic value because of its hard meat quality, few fish bones and high nutritious value. Esox reieherti had an extensive distribution before the 1950's, when there were obvious fishing seasons. In recent decades, E. reieherti decreased markedly as a fishery resource due to the destruction of its environment and overfishing ( $\mathrm{Li}$ et al, 2004). Esox reieherti has been listed as a new secondary protected animal in Aquatic conservation of wildlife of country directory.

Microsatellite DNA is dispersed throughout the eukaryotic genome, possessing high polymorphic information contents (PIC) and agreeing with Mendel's genetic mode and co-dominant expression. Microsatellite DNA is applied widely in population genetic structure analyses, detection of genetic diversity, construction of genetic maps, loci analysis linked with production character and QTL analysis (Liu et al, 2007; Postlethwait et al; Sun \& Liang, 2000; Wang \& Wu, 2006; Zhang et al, 2007). Few resources can be untilized due to the lagger condition of microsatellite analysis in aquatic animals as opposed to land-dwelling animals and plants (Guo et al, 2007). Few studies have focused on $E$. reieherti microsatellite DNA marker isolation. We intended to obtain sufficient and effective microsatellite markers using a method of combining magnetic bead enrichment with radioactive hybridization protocol to construct E. reieherti microsatellite libraries, and thereby design and select corresponding PCR primers. This study can provide fundamental data for further research on $E$. reieherti populations, seed selection, genetic potential, utilization and protection of germ plasma resources, construction of genetic linkage maps and QTL location.

\section{Material and Methods}

\subsection{Material}

Esox reieherti samples used in the study were bought from aquatic markets in Harbin in August, 2006.

\subsection{Isolation of the high molecular weight genome}

Liver samples were taken out and put into mortar and rubbed in a liquid nitrogen solution. Liver powder, $0.1 \mathrm{~g}$, was put into a $1.5 \mathrm{~mL}$ tube, $0.5 \mathrm{~mL}$ of extraction buffer was added $(200 \mu \mathrm{g} / \mathrm{mL}$ proteinase $\mathrm{K}, 0.5 \% \mathrm{SDS}$, $200 \mathrm{mmol} / \mathrm{L}$ EDTA pH8.0), the tube was incubated at $50^{\circ} \mathrm{C}$. The solution was extracted three times using phenol/chloroform/isoamyl alcohol (25:24:1), and then dialyzed for 16 hours with $0.05 \mathrm{~mol} / \mathrm{L}$ Tris- $\mathrm{HCl}$ (pH8.0) and $0.01 \mathrm{~mol} / \mathrm{L}$ EDTA (pH8.0), precipitated with cold absolute alcohol, washed with 70\% ethanol, air-dried, and re-dissolved in $0.1 \times \mathrm{TE}$. One percent agarose gel electrophoresis was used to detect the purity quotient and the products were kept in a refrigerator at $4^{\circ} \mathrm{C}$.

\subsection{Digest with restriction enzyme and obtaining genomic DNA fragments}

Whole genomic DNA was digested with Sau 3AI, the products were visualized in $1 \%$ agarose gel, and then isolated by sucrose-density-gradient centrifugation method (four gradients including 10\%, 20\%, 30\% and $40 \%$ were used, $22000 \mathrm{r} / \mathrm{min}, 4^{\circ} \mathrm{C}, 22 \mathrm{~h}$ ), 400-900 bp fragments were collected for the next steps.

\subsection{Connecting the genomic DNA with linker}

1.4.1 Preparation of the Brown linker A double-stranded adaptor from a single stranded oligonucleotide was synthesized by mixing equal proportions of oligonucleotides. A (5'-GATCGTCGACGGTACCGAATTCT-3') and B (5'GTCAAGAATTCGGTACCGTCGAC 3'), made the final concentration of solution $25 \mu \mathrm{mol} / \mathrm{L}$. It was denaturalized at $95^{\circ} \mathrm{C}$ for $10 \mathrm{~min}$, and then cooled slowly down to $10^{\circ} \mathrm{C}$ over a period of 4 hours to form double-stranded adaptors:

\section{5'-GATCGTCGACGGTACCGAATTCT-A \\ 3'-CAGCTGCCATGGCTTAAGAACTG-B \\ Sau $3 A$ I $-S$ al I $-E c o R$}

1.4.2 Ligating the linkers A ligation system of $20 \mu \mathrm{L}$ was constructed, including $4 \mu \mathrm{L}$ ( about $400 \mathrm{ng}$ ) of enzyme digested fragments, $10 \mu \mathrm{L}$ of linkers, $1 \mu \mathrm{L} \mathrm{T} \mathrm{T}_{4} \mathrm{DNA}$ ligase ( Promega, USA ), $2 \mu \mathrm{L}$ ligation buffer, up to $20 \mu \mathrm{L}$ water. The mixture was kept at $16^{\circ} \mathrm{C}$ in a water bath overnight (about 12-14 h). It wasthen separated with cenerifugal concenerators (PALL FIL TRON Inc.), the residual linker discarded and the final product was concentrated to about $15 \mu \mathrm{L}$, and then detected in $1 \%$ agarose-gel to see whether the residual existed or not and whether the product appeared.

\subsection{Establishing Esox reieherti genomic PCR libraries}

PCR amplification was performed with $4 \mu \mathrm{L}$ of DNA fragments ligated with linkers as templates and Primer B as primers (PE9700 PCR amplifier). The PCR reactions consisted of an initial denaturing step of $3 \mathrm{~min}$ at $94^{\circ} \mathrm{C}$; 20 cycles for $1 \mathrm{~min}$ at $94{ }^{\circ} \mathrm{C}, 1 \mathrm{~min}$ at $58^{\circ} \mathrm{C}, 2 \mathrm{~min}$ at $72^{\circ} \mathrm{C}$; and a $10 \mathrm{~min}$ final extension step at $72^{\circ} \mathrm{C}$. After 
the reaction, the products were passed through cenerifugal concentrators and the residual primers and dNTP discarded. The volume was concentrated to about $15 \mu \mathrm{L}$, and then the concentration and size of the products was determined.

\subsection{Marking the microsatellite probes with biotin and making the Dynal magnetic beads hybrid- ize with genomic libraries}

1.6.1 Preparation of the hybridization buffer Construction of $50 \mu \mathrm{L}$ reaction system: the following materials were mixed: $1.5 \mu \mathrm{L}(10 \mu \mathrm{mol} / \mathrm{L})$ Probes $\left[(\mathrm{CA})_{12}\right.$ and $(\mathrm{GA})_{12}$ marked with biotin], $5 \mu \mathrm{L}$ Primer $\mathrm{B}(50$ $\mu \mathrm{mol} / \mathrm{L}), 15 \mu \mathrm{L} 20 \times \mathrm{SSC}(\mathrm{NaCl}$, sodium citrate, $\mathrm{HCl}$, $\mathrm{pH} 7.0), 0.5 \mu \mathrm{L} 10 \% \mathrm{SDS}, 16 \mu \mathrm{L} \mathrm{ddH}_{2} \mathrm{O}$, and the mixture warmed up to $68^{\circ} \mathrm{C}$. It was denaturalized for $5 \mathrm{~min}$ at $95^{\circ} \mathrm{C}$, the DNA fragments ligated with linkers and then amplified by PCR reaction, and immediately blended into the warmed hybridization solution at $68^{\circ} \mathrm{C}$, and hybridized in a hybridization oven for 1 hour.

1.6.2 Balancing the magnetic beads One hundred micro-litres of $(10 \mathrm{mg} / \mathrm{mL})$ magnetic beads were placed into a $500 \mu \mathrm{L}$ low viscosity silicide-based tube, and the tube was placed on the magnetic-forces shelves (MPC, Promega, USA) for $1-2 \mathrm{~min}$ and then the salt solution gently extracted. After washing the solution twice with $200 \mu \mathrm{L} \mathrm{B} \& \mathrm{~W}(10 \mathrm{mmol} / \mathrm{L}$ Tris-Cl, $1 \mathrm{mmol} / \mathrm{L}$ EDTA, 2 $\mathrm{mol} / \mathrm{L} \mathrm{NaCl}$ ), the magnetic beads were washed 3-5 times with $200 \mu \mathrm{L}$ lotion I $(6 \times \mathrm{SSC}, 0.1 \% \mathrm{SDS})$ until the beads were smooth and easy to elute. Finally $150 \mu \mathrm{L}$ of lotion I was added at the end of the hybridization.

1.6.3 Enrichment and capture The hybridization solution was added to the balanced magnetic beads, using streptavidin-labelled magnetic beads to capture the $25^{\circ} \mathrm{C}$ microsatellite sequences linked with biotin probes. The tube was gently shaken for $20 \mathrm{~min}$ to combine the streptavidin with biotin, and then placed in a silicide-based tube onto magnetic-force shelves. The magnetic beads were washed to discard non-differential DNA fragments. The washing process included: twice in lotion I $(6 \times \mathrm{SSC}, 0.1 \% \mathrm{SDS})$ at room temperature and once for $10 \mathrm{~min}$, twice in lotion II $(3 \times \mathrm{SSC}, 0.1 \% \mathrm{SDS})$ at $68^{\circ} \mathrm{C}$ and once for $15 \mathrm{~min}$; then $50 \mu \mathrm{L} 0.1 \times \mathrm{TE}$ was added in and denaturation occurred for $10 \mathrm{~min}$ at $95^{\circ} \mathrm{C}$. The supernatant was carefully extracted so a single-stranded DNA fragment containing microsatellite sequences was retrieved.

A $6 \mu \mathrm{L}$ single-stranded microsatellite sequence was used as a template and a second PCR amplification was performed, conditions were the same as the first time.
The residual primers and dNTP were discarded and the product concentrated to about $15 \mu \mathrm{L}$ and visualized in electrophoresis.

\subsection{Ligating $\mathrm{T}$-vector and clone}

The ligated reaction system was constructed using: $2 \times 5 \mu \mathrm{L}$ ligate buffers (containing ligase), 18-T $1 \mu \mathrm{L}$ vector pMD (Promega, USA), $3 \mu \mathrm{L}$ DNA fragment, asepsis up to $10 \mu \mathrm{L}$ deionized water and a T-vector was used as a reference. The ligation reaction was conducted for 3 hours at $16^{\circ} \mathrm{C}$. It was transformed with competent Escherichia coli DH5 $\alpha$ prepared from $\mathrm{CaCl}_{2}$ (Sambrook et al, 1989), and genomic microsatellite libraries were obtained.

\subsection{Second selection with isotope-labeling probes}

Second selection was performed by in situ hybridization. A clone was transferred to the hybridized membrane and the same size of bacterial plaque was kept to select the positive clone at the end. The hybridization was performed with $(\mathrm{CA})_{12}$ and $(\mathrm{GA})_{12}$ marked with an isotope, and visualized with X-radiation for 7 days.

\subsection{Detection of the sequence of positive clone and analysis of the result}

Positive clones were selected and sequenced by BEIJING NUOYASAI Genomic Research Center Inc. Vector sequences were cut after sequencing, and then a search for microsatellite recombined sequences was performed, by using software SSR Finder, to determine the repeat numbers and flank sequences. Primer design was accomplished according to conserved sequences flanked by repeat sequences, using software Primer Premier 5.0 and PCR amplifying groups, and visualized in agarose-gel and analysis of the primer application.

\section{Results}

\subsection{Esox reieherti microsatellite clone and sequence analysis}

One thousand six hundred positive clones were obtained from the genomic libraries in this study. Positive clone ratio before hybridization was $90.91 \%$, that is the ratio of T-vectors self-ligated at $9.09 \%$ (Fig. 1), therefore approximately 1455 recombined clone were obtained. After the second selection using hybridization, 1300 clones were obtained; the ratio of positive clones to whole ones was $81.25 \%$. One hundred and ninety-six clones were selected for sequencing, 192 (97.96\%) were found containing microsatellite sequences and included 209 microsatellite loci, consisting mainly of CA/GT, GA/CT repeat sequences, mono-nucleotide (A, T, G, C) and quad-nucleotide (GAGT, CTCA) and 
quint-nucleotide (CTCTC) repeat units. As shown in Fig. 2, CA/GT repeat times ranged from 5 to 30 , accounting for $75.43 \%$, concentrated 5-10 times, accounting for
$39.46 \%$, the greatest repeat time was $137 ; 25$ microsatellites containing $\mathrm{GA} / \mathrm{CT}$ and repeat times ranging from 5 - 10 were determined, 10 ones $(2.88 \%)$

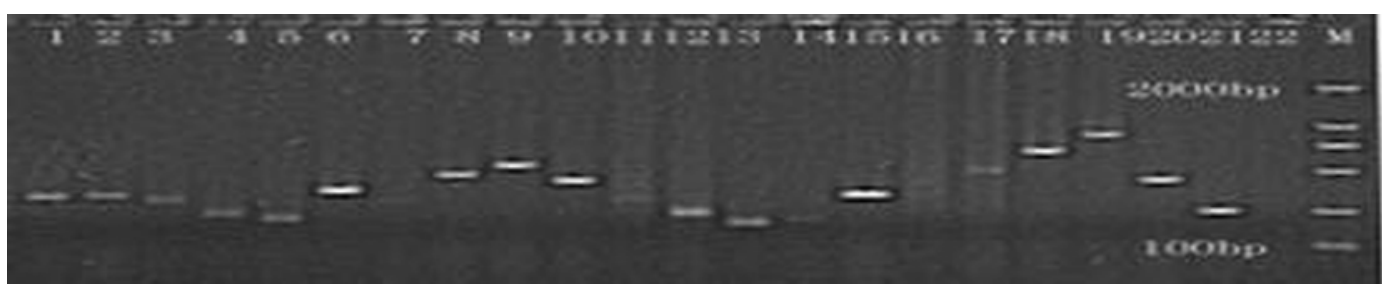

Fig. 1 Positive colonies distribution of microsatellites in the first round of screening M: DNA marker DL 2000; 1 - 22: Colonies.

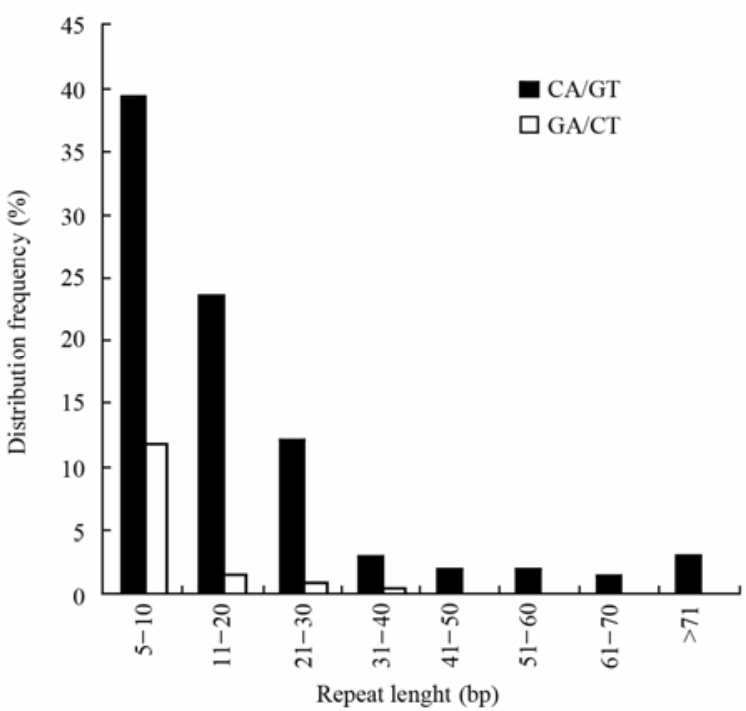

Fig. 2 Length distribution of microsatellite in the genome of Esox reieherti Dybowski

repeated over 7 times, the greatest occurred among 5 10 , accounting for $11.74 \%$, the greatest repeat time was 40. According to Weber (1990), these microsatellites can be classified into three types: Perfect, Imperfect and Compound. Perfect types are repeat sequences in which no intermittence occurs and no other repeat sequences exist near it. Imperfect are when two or more repeat sequences are segmented by non-repeat sequences, under three nucleotides; Compound types are when one repeat sequence and other repeat sequences are segmented by non-repeat sequences under three nucleotides. Our results included 132 Perfect microsatellites (63.16\%), 48 Imperfect sort (22.97\%) and 29 (13.88\%) Compound types.

\subsection{Designation of primers for the double-nucleotide repeat sequence and selection}

Primers were designed according to preserved sequences flanking the double-nucleotide repeat sequence by using software Primer Premier 5.0. Some sequences could not be used to design primers, 192 microsatellite sequences obtained 70 primers (partial primer sequence shown in Tab. 1). Selecting and synthesising 32 primers, optimized the PCR reaction conditions, 28 primers amplified clear and repeatable bands. Fig. 3 is the amplification result of marker HLJGY12.

Tab. 1 Parts of microsatellite primer pairs for Esox reieherti Dybowski

\begin{tabular}{|c|c|c|c|c|c|}
\hline $\begin{array}{l}\text { Microsatellite } \\
\text { marker }\end{array}$ & Primer sequence 5' $-3^{\prime}$ & $\begin{array}{l}\text { Size } \\
(\mathrm{bp})\end{array}$ & Repeat motif & $\begin{array}{c}\text { Optimum } \\
\text { annealing } \\
\text { temperature } \\
\left({ }^{\circ} \mathrm{C}\right) \\
\end{array}$ & Type \\
\hline HLJGY1 & $\begin{array}{l}\text { F:ACTGTCCCTGTTATCC } \\
\text { R:TCCCTGGCTCACTAAC }\end{array}$ & 177 & $(\mathrm{GT})_{45}$ & 50 & $P$ \\
\hline HLJGY3 & $\begin{array}{l}\text { F:GGCTGGATTTCGGTGGA } \\
\text { R:ACCTGCGGGTCAAGAGC }\end{array}$ & 168 & $(\mathrm{CA})_{12}$ & 50 & $P$ \\
\hline HLJGY4 & $\begin{array}{l}\text { F:GCCTAAACGCAGTAGTCAA } \\
\text { R: TGGAGAAAGTGGGACA }\end{array}$ & 393 & $(\mathrm{GT})_{66}$ & 55.5 & $P$ \\
\hline HLJGY5 & $\begin{array}{l}\text { F: CCAAGCATAGCCACCC } \\
\text { R: CTCCGCAATCTCAGCA }\end{array}$ & 365 & $\begin{array}{l}(\mathrm{GT})_{25}(\mathrm{GA})(\mathrm{GT})_{4}(\mathrm{GA})(\mathrm{GT})_{4}(\mathrm{GA})(\mathrm{GT})_{34} \\
(\mathrm{GT})_{49}\end{array}$ & 56 & I \\
\hline HLJGY6 & $\begin{array}{l}\text { F: ACCATCCCATTGACTT } \\
\text { R: TAAACAACGCCCACTC }\end{array}$ & 293 & $(\mathrm{GT})_{44}$ & 51 & $P$ \\
\hline
\end{tabular}


(continued)

\begin{tabular}{|c|c|c|c|c|c|}
\hline $\begin{array}{l}\text { Microsatellite } \\
\text { marker }\end{array}$ & Primer sequence 5' $-3^{\prime}$ & $\begin{array}{l}\text { Siz } \\
\text { (bp }\end{array}$ & Repeat motif & $\begin{array}{c}\text { Optimum } \\
\text { annealing } \\
\text { temperature } \\
\left({ }^{\circ} \mathrm{C}\right)\end{array}$ & Type \\
\hline HLJGY7 & $\begin{array}{l}\text { F: TGTGCTGTGGCTAATG } \\
\text { R: CAAATCCAGGGTGAGT }\end{array}$ & 226 & $(\mathrm{GT})_{56}$ & 50 & $P$ \\
\hline HLJGY8 & $\begin{array}{l}\text { F: GAGACTGAAGCAATAG } \\
\text { R: AAGAGTAGTAAAGATAAG }\end{array}$ & 249 & $(\mathrm{GT})_{51}(\mathrm{GTG})(\mathrm{GT})_{18}$ & 58 & $\mathrm{P}$ \\
\hline HLJGY9 & $\begin{array}{l}\text { F: CTGCTGGGTTGAAGTA } \\
\text { R: AGAGGAGGGTGGATGT }\end{array}$ & 335 & $(\mathrm{CA})_{22}$ & 60 & I \\
\hline HLJGY10 & $\begin{array}{l}\text { F: ATTCCTGGCTCGGTTTC } \\
\text { R: AAATGGTGCCGAAGTT }\end{array}$ & 102 & $(\mathrm{CA})_{26}(\mathrm{CG})(\mathrm{CA})_{21}$ & 59 & $\mathrm{P}$ \\
\hline HLJGY11 & $\begin{array}{l}\text { F: CGTCCACTTCCAACAG } \\
\text { R: GGTGGATGATTAGGGA }\end{array}$ & 150 & $(\mathrm{CA})_{9}$ & 60 & I \\
\hline HLJGY12 & $\begin{array}{l}\text { F: GGGTCACAGCCTCCAT } \\
\text { R: GGCGTCCCGTGATTTA }\end{array}$ & 184 & $(\mathrm{GT})_{41}$ & 60 & $\mathrm{P}$ \\
\hline HLJGY13 & $\begin{array}{l}\text { F: TCCACCAAACACGACA } \\
\text { R: AAACAAAATGACACCC }\end{array}$ & 227 & $(\mathrm{GT})_{21}$ & 56 & $\mathrm{P}$ \\
\hline HLJGY14 & $\begin{array}{l}\text { F: CAGGCAGCAGGTAAAG } \\
\text { R: CGGTCCAGGTCACTCT }\end{array}$ & 177 & $(\mathrm{CA})_{12}(\mathrm{CT})_{3} \ldots \ldots(\mathrm{CG})(\mathrm{CA})_{57}$ & 56 & $\mathrm{P}$ \\
\hline HLJGY15 & $\begin{array}{l}\text { F: GGAAGTTGCCTTTGGA } \\
\text { R: GCTGAATGGAGGGACA }\end{array}$ & 435 & $\begin{array}{l}(\mathrm{GT})_{2}(\mathrm{TT})(\mathrm{GT})_{3} \\
(\mathrm{TT})(\mathrm{GT})_{35}\end{array}$ & 59 & $\mathrm{C}$ \\
\hline HLJGY16 & $\begin{array}{l}\text { F: GCAAATGCTGACAGGGAC } \\
\text { R: GCAGTGCGATGGATGG }\end{array}$ & 168 & $(\mathrm{GT})_{75}$ & 51 & I \\
\hline HLJGY17 & $\begin{array}{l}\text { F: CTGATTGCGTTGCTAA } \\
\text { R: GACAAAGATGCGGGAC }\end{array}$ & 225 & $(\mathrm{GT})_{13}$ & 50 & $\mathrm{P}$ \\
\hline HLJGY18 & $\begin{array}{l}\text { F: GAGCAGGACGGACCAGA } \\
\text { R: TCCСТCTTCCACСCTA }\end{array}$ & 133 & $(\mathrm{GT})_{60}$ & 50 & $\mathrm{P}$ \\
\hline HLJGY19 & $\begin{array}{l}\text { F: CCCATGAGGGTAGCTG } \\
\text { R: GCTGTCGGTATTGCTG }\end{array}$ & 199 & $(\mathrm{GT})_{34}$ & 55 & $P$ \\
\hline HLJGY21 & $\begin{array}{l}\text { F:ACTGGAGTAATGATGCTGAA } \\
\text { R: TTGAAGAATTGGTCGC }\end{array}$ & 390 & $\begin{array}{l}(\mathrm{GT})_{8}(\mathrm{CT})(\mathrm{GT})_{9} \\
(\mathrm{GT})_{8}(\mathrm{GA})_{2}(\mathrm{GT})_{5}\end{array}$ & 60 & $\mathrm{P}$ \\
\hline HLJGY22 & $\begin{array}{l}\text { F: ACGGTCTAGGTTTGAT } \\
\text { R: CAACAACTTCACCAAC }\end{array}$ & 142 & $(\mathrm{CA})_{8}$ & 50 & $\mathrm{P}$ \\
\hline HLJGY23 & $\begin{array}{l}\text { F: ACGATCCGAGACTCCT } \\
\text { R: TGACCACTGTGAACCC }\end{array}$ & 110 & $\begin{array}{l}(\mathrm{GT})_{8}(\mathrm{AT})(\mathrm{GT})_{18} \\
(\mathrm{GG})(\mathrm{GT})_{5}\end{array}$ & 60 & I \\
\hline HLJGY24 & $\begin{array}{l}\text { F: GTCGACGAGCTCATTA } \\
\text { R: TAACGGACCCCTAAGA }\end{array}$ & 319 & $(\mathrm{GT})_{34}(\mathrm{GA})(\mathrm{GT})_{2}$ & 319 & $\mathrm{P}$ \\
\hline HLJGY25 & $\begin{array}{l}\text { F: ACGGTTGAGCTATTCT } \\
\text { R: ACCTCATTGTTTCCTG }\end{array}$ & 132 & $(\mathrm{GT})_{66} \ldots \ldots(\mathrm{GT})_{3}$ & 51 & I \\
\hline HLJGY26 & $\begin{array}{l}\text { F: CGACGGTCTTGGAAAA } \\
\text { R: GAGGGATAGGTTGGTAGTG }\end{array}$ & 419 & $(\mathrm{GT})_{88}$ & 50 & I \\
\hline HLJGY28 & $\begin{array}{l}\text { F: CCAGCAGTAACTCAAAG } \\
\text { R: CGGGCTGATTAAGTAAGA }\end{array}$ & 453 & $\begin{array}{l}(\mathrm{CA})_{16}(\mathrm{TA})(\mathrm{CA})_{35} \\
(\mathrm{TA})(\mathrm{CA})_{48} \\
\end{array}$ & 60 & $\mathrm{P}$ \\
\hline HLJGY29 & $\begin{array}{l}\text { F: CGACGGTCCCATTACA } \\
\text { R: ATGGTCCTCATTTCTG }\end{array}$ & 287 & $(\mathrm{CA})_{98}$ & 60 & I \\
\hline HLJGY30 & $\begin{array}{l}\text { F: CCTCGCTATGACAAAT } \\
\text { R: GTGGTCAGCAGGAGAT }\end{array}$ & 294 & $(\mathrm{GT})_{22}$ & 60 & $\mathrm{P}$ \\
\hline HLJGY31 & $\begin{array}{l}\text { F: ACTTACCACATGACCACCTT } \\
\text { R: GCACGCCCGACAAACA }\end{array}$ & 223 & $(\mathrm{GA})_{20}$ & 56 & $\mathrm{P}$ \\
\hline HLJGY32 & $\begin{array}{l}\text { F: TTTCACTAGACGACCAC } \\
\text { R: TAAACTGCCACTCCAC }\end{array}$ & 139 & & 50 & $\mathrm{P}$ \\
\hline
\end{tabular}

F: Forward primer; R: Reverse primer; P: Perfect; I: Imperfect; C: Compound. 


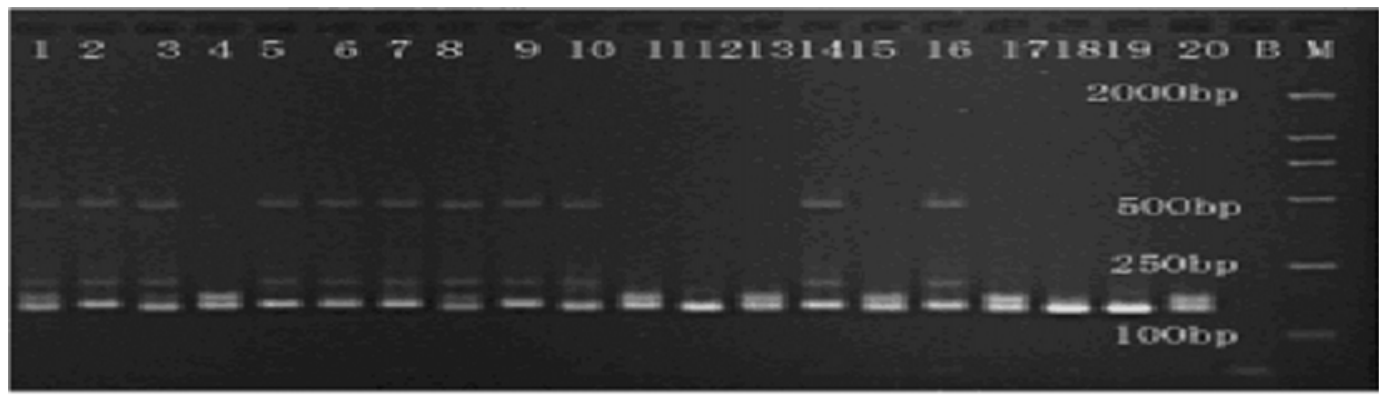

Fig. 3 Analysis of PCR products for the HLJGY12 locus in Esox reieherti Dybowski M: DNA marker DL 2000; 1 - 20: 20 individuals; B: Negative control.

\section{Discussion}

The common way of obtaining microsatellite flanking sequences is to construct genomic libraries enriched in microsatellite loci, and the key to microsatellite loci analysis are the microsatellite flanking sequences. The microsatellite loci genomic libraries can be constructed in two ways: one is to found a genomic DNA library by classical molecular biological methods, such as performing Southern hybridization with manual radioactivity isotope labels or non-radioactivity label probes, selecting positive clones and sequencing them. This method is simple but has a low efficiency, the ratio of positive clone to the whole is only $2 \%-3 \%$, and it requires a lot of labor and funding. The second way is enrichment protocol with biotin-labelled magnetic beads to isolate microsatellite molecular markers, suggested by Kijas et al (1994) and is a method of rapidly separating microsatellite sequences. This protocol is founded on the basis of covalence combination theory between streptavidin-labelled on the face of magnetic beads and biotin-labelled on the microsatellite probes. This method can potentially separate several hundred microsatellite loci in a short time; especially applicable to animals possessing low numbers of microsatellite sequences. Magnetic beads enrichment protocol is a simple and highly efficient method (Bronw et al, 1995; Kandpal et al, 1994). It can improve the ratio of obtaining microsatellite positive clones by up to 50\% ( $\mathrm{Li} \&$ Zheng, 2004) and therefore is applied broadly to select microsatellite loci (Edwards et al, 1996; He et al, 2003; Carleton et al, 2002; Sun et al, 2005). Cifarelli et al (1995) suggested RAHM (Random Amplified Hybridization Microsatellites), Lunt et al (1999) proposed PIMA (PCR Isolation of Microsatellite Arrays), these two methods aim to enrich microsatellites on the basis of RAPD products but has a low efficiency and obtains microsatellites randomly although avoiding the construction of a genomic library.
Lian et al (2001) linked the synthesized linker at the ports of the digested DNA fragment and substituted manual linker sequences for vector sequences. This method can only obtain single-sided sequences of microsatellites once and requires a large amount of time and expenses to be invested. Combined with the above protocols, this study performed the method combining magnetic beads with radioacte hybridization protocol, ligating synthesized linkers, designing primers according to linker sequence, amplifying digested DNA fragments captured by probes and enriching microsatellites. The synthesized linker increased the specificity so the flank sequence could be obtained from one clone sequence, and therefore being more cost-effective. On the other hand applying the second hybridization can improve the ratio of microsatellite sequences acquired. In this research 196 positive clones were selected to sequence after the second hybridization selection. As a result, 192 $(97.96 \%)$ clones were found including microsatellite sequences, Quan (Quan et al, 2006) sequenced 173 clones and $178(97.19 \%)$ clones included microsatellite sequence; Lu et al (2005) sequenced 138 clones and 149 $(92.62 \%)$ clones included microsatellite sequences, prior to obtaining the ratio in the above results. As shown in this paper, 1300 positive clones were acquired from 1600 microsatellite clones, the ratio was $81.25 \%$, far greater than congeneric results (Sun et al, 2005; Quan et al, 2006; Lu et al, 2005; Refseth et al, 1997).

The abundance ratio of different nuclear repeat units differed in the genome, and it was the foundation for selecting microsatellite molecular markers, therefore, it was important to confirm the abundance ratio before selecting the microsatellite marker. In all the animals, microsatellites containing $\mathrm{CA} / \mathrm{GT}$ is the most abundant and GA/CT the second (Brenner et al, 1993). Oligonucleotide probes containing $\mathrm{CA} / \mathrm{GT}$ and GA/CT repeat sequences were employed in this study, CA/GT accounts for $86.3 \%$, GA/CT accounts for $13.62 \%$, which 
confirmed the above conclusion. There were 132 Perfect microsatellites (63.16\%), 48 Imperfect (22.97\%) and 29 Compound types $(13.88 \%)$ in this study. Perfect types were the most abundant, in accordance with the microsatellite characteristics in carp (Sun et al, 2005), northern catfish (Quan et al, 2006) and silver carp (Lu et al, 2005). The main reason for this ratio in this study may be due to the fact that there were two selections of microsatellite sequences in the magnetic beads enrichment protocol. One used a probe connecting biotin and containing $(\mathrm{CA})_{12},(\mathrm{GA})_{12}$ repeat sequences. Many residual repeat sequences in hybridization elution were discarded using this method. The second selection used isotope probes selection containing $(\mathrm{CA})_{12},(\mathrm{GA})_{12}$ repeat sequences to compare with the normal magnetic beads enrichment protocol, which discarded most of the low repeat sequences. The two selection processes in this enrichment protocol may be the reason such a high number of good microsatellite sequences were obtained (Sun et al, 2005).

The number of microsatellite oligonucleotide repeat units makes a great difference in different species, and has rich polymorphism. Valdes (1993) held that that microsatellite whose number of repeat units is lower than five in humans hardly displays any polymorphism. Smulders (1997) thought that more repeats could produce both interspecific and intraspecific polymorphism, however, few repeats can only produce interspecific polymorphism. Other related studies showed that microsatellites in length are mostly lower than thirty repeat units, and the sequence is relatively long $(100 \mathrm{bp} \pm)$, Taq enzymes are easy to splice in PCR amplification, shadow bands visualized in electrophoresis and counting of the bands could have led to errors. About $68.99 \%$ of microsatellites in Northern catfish (Quan et al, 2006) have repeat sequences lower than thirty times, about $77.5 \%$ of microsatellite repeat sequences in abalone are lower than thirty times. In this

\section{References:}

Brenner S, Elgar G, Sandford R, Sanford R, Macrae A, Venkatesh B, Aparicio S. 1993. Characterization of the pufferfish (Fugu) genome as a compact model vertebrate genome[J]. Nature, 366: 265-268.

Bronw J, Hardwick LJ, Wright AF. 1995. A simple method for rapid isolation of microsatellites from yeast artificial chromosomes[J]. Molecular and Cellular Probes , 9:53-58.

Carleton KL,Streelman JT, Lee BY, Garnhart N, Kidd M, Kocher TD. 2002. Rapid isolation of CA microsatellites from the tilapia genome[J]. Animal Genetics, 33(2): 140-144. study, $75.43 \%$ of $E$. reieherti microsatellite DNA repeat units were lower than thirty, close to the ratio of the two above species, microsatellite DNA repeat units.

The enrichment protocol to prepare microsatellites can improve the efficiency by mending the experimental method, but some key steps are also important. Obtaining high quality DNA is the foundation of the experiment, it is also important to collect fragments after sucrose density gradient centrifugation and avoid short insertion fragments, which are needed to design primers (Li \& Zheng, 2004). The enrichment of magnetic beads is the key step in the whole experiment; it influences directly the quality of clone microsatellites (Quan et al, 2006). The balance of magnetic beads has to be carefully controlled, washed at a specific temperature and washed for a specific number of hours. The magnetic beads must be balanced again and again by using a salt solution before using the magnetic beads, so they can become smooth. This step is to wash away residual fragments not containing microsatellites, so only fragments rich in microsatellite sequences can be preserved on the face of magnetic beads.

Among humans and some important animals and plants, the predominant characteristic microsatellite markers can be applied broadly to population genetic structure analyses, molecular assistant breeding, genetic map construction, productive trait linked analysis and QTL orientation. However, selection and isolation of microsatellites has not been reported until now. This study constructed E. reieherti partial genomic libraries, designed and selected some microsatellite markers able to be stably amplified in the genome, providing foundation data for $E$. reieherti and neighbor species populations in selected breeding, genetic potential, as a germ plasma resource utilization and preservation, genetic linkage map construction, QTL orientation and other further studies.

Cifarelli RA, Gallitelli M, Cellini F. 1995. Fandom amplified hybridization microsatellites (RAHM): isolation of a new class of microsatellite-containing DNA clones[J]. Nucleic Acids Research, 23: 3802-3803.

Edwards KJ, Barker JH, Daly A, Jones C, Karp A. 1996. Microsatellite libraries enriched for several microsatellite sequences in plants[J]. Biotechniques, 20(5): 758-760.

Guo YS, Wang ZD, Liu CW, Liu J. 2007. Rapid isolation and characteristics analysis of microsatellites from Lutjanus russelli[J]. Hereditas (Beijing), 29(3): 355-359. 
He GH, Meng RH, Newman M, Gao G, Pittman RN, Prakash CS. 2003. Microsatellites as DNA markers in cultivated peanut (Arachis hypogaea L) [J]. BMC Plant Biology, 97: 143-149.

Kandpal RP, Kandpal G, Weissman SM. 1994. Construction of libraries enriched for sequence repeats and jumping clones, and hybridization selection for region specific markers[J]. Proc Natl Acid Sci USA, 91: 88-92.

Kijas JM, Fowler JC, Garbett CA. 1994. Enrichment of microsatellites from the citrus genome using Bi-Otinylated oligonucleotide sequences bound to strep tavid in-coated magnetic particles[J]. Biotechniques, 16: 657-662.

Li YS, Zhao CG, Dong CZ. 2004. Study on fishery biology of Esox reieherti Dybowski in Heihe reach of upper reaches of Heilongjiang river[J]. Heilongjiang Fisheries, 3: 43-44,48.

Li MF, Zheng XQ. 2004. Development of SSR markers in litchi (Litchi chinenis) [J]. Hereditas (Beijing), 26(6): 911-916.

Li MF, Zheng XQ. 2004. Research progress of methods of SSR primers development[J]. Hereditas (Beijing), 26(5): 769-776.

Lian CL, Zhou ZH, Hogetsu T. 2001. A simple method for developing microsatellite markers using amplified fragments of inter-simple sequence repeat[J]. J Plant Research, 114 : 381-385.

Liu Z, Lu SQ, Kuang GQ, Zhang JS, Liu HY, Liu F. 2007. Microsatellite DNA analysis on genetic diversity of culturedand wild Cyprinus carpio populations in Xiangjiang River[J].Chinese Journal of Ecology, 26(7): 1074-1079.

Lu CY, Sun XW, Cao J, Liang LQ. 2005. Microsatellite enrichment by magnetic beads in silver carp (Hypophthalmichtys molitrix) [J]. Journal of Agricultural Biotechnology, 13(6): 772-776.

Lunt DH, Hutchinsom WF, Carvalho GR. 1999. An efficient method for PCR-based identification of microsatellite arrays (PIMA) [J]. Molecular Ecology, 8: 893-894.

Postlethwait JH, Yan YL, Gates MA. 1998. Vertebrate genome evolution and the zebraflsh gene map $[\mathrm{J}]$. Nature Genetics. 18: 345-349.

Quan YC, Sun XW, Liu W, Liang LQ, Lu CY. 2006. Microsatellite enrichment by magnetic beads in Silurus meriaionalis[J]. Journal of fisheries of China, 30(2): 185-191.

Refseth UH, Fangan BM, Jakobsen KS. 1997. Hybridization capture of microsatellites directly from genomic DNA[J]. Electrophoresis, 18: 1519-1523.

Sambrook J, Fritsch EF, Maniatis T (Translated by Jin DY, Li MF, Hou LD). 2002. Experimental Directory of Molecular Clone (3rd ed)[M]. Beijing: Science Press, 96-99.

Smulders JM. 1997. Use of short microsatellites from detabase sequences to generate polymorphisms among lycopersicon esculentum cultivates and accessions of other lycopersicon species[J]. Theor Appl Genet, 97: 264-272.

Sun XW, Jia ZY, Wei DW, Lu CY, Liang LQ. 2005. Comparison between magnetic beads enriched and small inserted fragment library for microsatellite sequences of common carp[J]. Journal of Fishery Sciences of China, 12(2): 192-196.

Sun XW, Liang LQ. 2000. A genetic linkage map of common carp[J]. Journal of Fishery Sciences of China, 7(1): 1-5.

Valdes AM. 1993. Allele frequencies at microsatellite loci: the stepwise mutation model revisited[J]. Genetics, 133: 737-749.

Wang GF, Wu DJ. 2006. Correlation analysis of microsatellite DNA markers with wool traits in liangshan semi-fine wool sheep[J]. Hereditas (Beijing), 8(12): 1505-512.

Weber JL. 1990. Informativeness of human $(\mathrm{dC}-\mathrm{dA})_{n} \quad(\mathrm{dG}-\mathrm{dT})_{n}$ polymorphisms[J]. Genomics , 7: 524-530.

Zhang Y, Liang LQ, Chang YM, Hou N, Lu CY, Sun XW. 2007. Mapping and genetic effect analysis of common carp (Cyprinus carpio L.) quantitative trait loci related to body size[J]. Hereditas (Beijing), 29(10): 1243-1248.

\section{更 正}

发表于本刊第 29 卷第 1 期第 69 页的 “云南鱼类三新纪录及驰娘胎江鱼类的区系存在度分析”一文, 由于作者和编辑的疏忽, 存在以下错误, 给读者带来不便, 特向读者表示谦意, 并更正如下:

1 第 75 页附录 I 第 24 行、花鲑拉丁种名, 原为 “maculates”，应为 “maculatus”;

2 第 75 页附录 I 第 27 行, 棒花鱼拉丁属名, 原为 “Abbotina”, 应为 “Abbottina”;

3 第 75 页附录 I 倒数第 3 行, 细身光唇鱼拉丁种名, 原为 “75longates”, 应为 “ elongatum”;

4 第 76 页第 7 行，桂孟加拉鲮拉丁种名，原为 “decora”，应为 “decoras”;

5 第 76 页第 13 行, 双珠盘鮈拉丁种名, 原为 “bismaritus”，应为 “bismargaritus”;

6 第 76 页第 37 行，鲇科拉丁名，原为 “Siluriformes”，应为 “Siluridae”。 